\section{STRATEGI PEMBELAJARAN SENI LUKIS ANAK USIA DINI DI SANGGAR PRATISTA YOGYAKARTA}

\section{Tri Hartiti Retnowati}

Fakultas Bahasa dan Seni Universitas Negeri Yogyakarta

Abstract

The aim of this study are to know instructional strategy on painting art for pre-schooler children at Sanggar Pratista Yogyakarta. The subjects on thi study are pre-schooler children and the teacher who follow the actvity at this place. The data get by using observation, interview, and documentation. The data were analyzed by using descriptive approach on two step. The first step analyzed data has been done during collected data from observation, interview, and documentation. All the data were reducted to get the main information that will be used on this study. The second step all the main information that get from first step were served reguraly to make conclution about this study. The finding show that the instructional stategy on painting art for pre-schooler finding show pildren used indivally instructional model with giving examples method. The purpose of giving examples was to give early model and than the children has to continue the examples that has been given by the teacher. The giving examples method was effective to motivate children on expressing skill, coloring skill, and find new object on their painting.

Keywords: instructional strategy, giving examples method, indivually instructional model

\section{PENDAHULUAN}

\section{Latar Belakang Masalah}

Anak adalah masa depan bangsa yang harus ditumbuhkembangkan jiwa dan raganya untuk menjadi anak yang cerdas, terampil dan berahlak mulia. Anak usia dini harus dikembangkan motorik kasar dan motorik haluasnya melalui kegiatan berkesenian, berketerampilan melalui kegiatan bermain. Bagi anak bermain adalah belajar atau belajar seraya bermain. Bagaimana menciptakan permainan yang dapat mengembangkan pertumbuhan fisik melalui motorik kasar dan bagaimana mengembangkan motorik halus melalui kegiatan kesenian. Sekarang pendidikan anak usia dini dikembangkan secara luar biasa melalui kegiatan prasekolah maupun kegiatan lembaga seperti RT, RW, dan pemerintah kelurahan memiliki kader dan kegiatan PAUD.

Mencermati fenomena itu perlu adanya reformasi dunia pendidikan yang mendasar. Pertama dilakukan pada sistem pendidikan, yakni sistem pendidikan tradisional direformasi menjadi sistem pendidikan empowering of people. Hal ini dilakukan karena pendidikan gaya lama (tradisional) menganggap siswa sebagai objek yang harus menerima apa saja yang diberikan guru. Kedua dilakukan pada orientasi pendidikan. Orientasi pendidikan kita terlalu menekankan pada aspek kognitif tingkat rendah, sedangkan aspek-aspek kepribadian lainnya yang justru lebih penting, seperti aspek afektif dan psikomotorik terabaikan.

Penelitian ini mencoba mengungkap dan mengembangkan pembelajaran kesenian (seni rupa anak) di Sanggar Pratista Yogyakarta. Sanggar Prastista adalah arena kegiatan pembelajaran seni lukis anak nonformal terbesar dan terkenal di Yogyakarta. Sanggar ini telak mencetak seniman-seniman kecil terkemuka yang telah mengukir prestasi lomba lukis tingkat daerah, Nasional, Asean, bahkan tingkat International. Bagaimana strategi Sanggar Pratista mengembangkan model pembelajaran kepada pesertta didiknya menjadikan anak dapat belajar melukis dengan baik.

Permasalah pada penelitian ini dibatasi pada: 1) Bagaimanakah strategi pembelajaran seni lukis anak di Sanggar Pratista?. 2) Bagaimana menyiapkan media pembelajaran seni lukis anak yang digunakan di sanggar Pratista?, 3) Model pembelajaran apa yang dikembangkan sehingga anak dapat berkarya seni lukis dengan baik?, 4) Bagaimana menilai proses anakdalam berkarya seni lukis?, 5) Bagaimana menilai hasil karya seni lukis anak?, 6) Bagaimana menciptakan lingkungan yang kondusif untuk belajar melukis bagi anak?

\section{Kerangka Teori}

\section{Pengertian Pembelajaran}

Konsep dasar pembelajaran pada dasarnya adalah satu rangkaian dengan konsep belajar dan mengajar. Menurut aliran behaviorisme Kemis, S. \& Mc Taggart, R. (1998) Learnring is a change in behavior, kata kunci dalam difinisi ini belajar adalah perubahan tingkah laku. Menurut Mattil Edward (1971) aliran kognitif, Learning is a change in human disposition or capability, which persist over a period of time, and which is not simply ascribable to procces of growth. Kata kunci dari definisi Gagne belajar adalah suatu perubahan watak atau kemampuan manusia yang berlangsung selama jangka waktu dan tidak sekedar menganggapnya proses pertumbuhan.

Menurut Hamalik Umar (1994) belajar adalah suatu aktivitas mental/psikis yang berlangsung dalam interaksi aktif dengan lingkungan, yang menghasilkan perubahan-perubahan dalam pengetahuan, pemahaman, ketrampilan, dan nilai sikap. Perubahan itu bersifat secara relatif konstan dan berbekas. Dari pengertian tersebut pada prinsipnya belajar adalah perubahan perilaku manusia dari hasil pengalaman berinteraksi dengan lingkungannya.

Pada prinsipnya mengajar adalah proses yang terjadi pada guru bagaimana menyampaikan materi pelajaran kepada anak didiknya. Mengajar pada prinsipnya adalah membina bagaimana belajar, berpikir, berlatih untuk penguasaan suatu pengetahuan, keterampilan dan perubahan sikap. Mengajar 
menurut Tilaar HAR (1999) adalah seni untuk mentranfer pengetahuan, ketrampilan, dan nilai-nilai yang diarahkan oleh nilai-nilai pendidikan kebutuhan siswa. Kondisi lingkungan, dan keyakinan yang dimiliki guru.

Adapun pembelajaran seni dan keterampilan pada prinsipnya adalah pembelajaran untuk mengembangkan apresiasi dan kreasi peserta didik. Proses penanaman nilai estetik, terampil, dan kreatif, tekun akan lebih bermakna jika anak mengalami proses langsung berinteraksi dengan berbagai kegiatan berkesenian. Pembelajaran seni rupa anak usia dini memberikan apresiasi kepada anak sebagai bekal untuk pembentukan pengalaman estetik, pengembangan kreativitas, dan keterampilan anak dalam mengaktualisasikan gagasan sesuai bahasanya Pembelajaran kesenian dan keterampilan pada esensinya adalah bermain pembelajaran melalui bermain yang baik adalah bermain yang menyenangkan bag anak, sehingga dapat mengembangkan imajinasi, kreasi sehingga anak dapat berkembang dengan baik dan wajar.

\section{Fembelajaran Anak Usia Dini}

Pembelajaran Seni Budaya dan Keterampilan anak usia dini harus memperhatikan:

1) Perkembangan anak.

Anak akan dapat belajar dengan baik jika anak merasa aman dan senang dalam situasi belajar. Untuk mewujudkan itu anak harus terpenuhi kebutuhan fisiknya seperti makan dan minum yang cukup dan secara psikologis aman dan senang dalam melakukan aktivitas. Jika proses pembelajaran anak tidak dalam kondisi yang menyenangkan niscaya akan sulit untuk mengembangkan potesi anak secara wajar, baik, dan maksimal. Tugas pembelajaran keterampilan adalah untuk mengembangkan potensi anak melalui bermain dengan keterampilan. Pililah jenis keterampilan yang menarik dan disenangi anak.

2) Kebutuhan Anak

Seribu anak akan memiliki seribu keinginan, apakah kita sebagai pembimbing anak akan mampu melayani keinginan tersebut. Tugas pembimbing bukan memenuhi keinginan anak tersebut akan tetapi memupuk, mengarahkan, dan membina anak agar keinginan tersebut tersalurkan dalam kontek pembelajaran. Anak akan dapat bermain dan belajar dengan baik kalau kebutuhan fisiknya tercukupi.

3) Bermain sambil belajar

Dunia anak adalah dunia bermain, jika anak bermain adalah belajar mungkin berbeda dengan orang dewasa bermain mempunyai konotasi negatif. Anak belajar melalui bermain, apalagi belajar seni dan keterampilan yang memiliki nilai permainan dan rekreasi. Tugas pembimbing adalah bagaimana mengemas materi seni lukis dan keterampilan anak usia dini yang menarik dan dapat dilakukan sambil bermain. Ini adalah tugas pembimbing yang harus memberikan materi sesuai perkembangan anak. Bentuk bermain anak dapat berupa bermain sosial, bermain dengan benda, dan bermain sosiodramatis. Keterampilan anak usia dini dalam melukis banyak yang berhubungan dengan permainan, maka siapkan permainan yang dapat mengembangkan kreativitas dan keterampilan anak. Horal Titus dalam Gie (1996:28) mengatakan "Play is the art of the child, and art is the play of the adult" Permainan adalah seni dari anak-anak, dan seni adalah permainan orang dewasa.

4) Pendekatan tematik

Pembelajaran keterampilan adalah pembelajaran bermain, anak akan bermain dan belajar dengan baik jika tema bermain sesuai dengan perkembangan dan menyenangkan. Untuk itu, pembimbing harus dapat memilih dan menentukan tema sesuai dengan kehidupan anak yang paling aktual dan kontekstual.

5) Kreatif dan inovatif

Tugas pembelajaran keterampilan adalah mengembangkan kreativitas anak, pilihlah jenis keterampilan yang dapat menggali imajinasi dan mengembangkan kreativitas anak. Pengembangan ide baru yang menantang dan inovatif dapat memotivasi dan menumbuhkan kreativitas anak. Fungsi pembelajaran seni dan keterampilan adalah untuk mengembangkan sensitivitas, kreativitas, dan keterampilan. Anak akan bermain untuk belajar berimajinasi untuk mengembangkan kreativitas tersebut.

6) Lingkungan kondusif

Pendidikan anak usia dini dapat dikondusikan dengan lingkungan yang nyaman dan aman untuk bermain dan belajar. Hal ini penting untuk pelalaksanaan proses belajar dan bermain anak, lingkungan anak yang sesuai dengan dunia anak dan dapat mengembangkan fantasi anak.

7) Mengembangkan kecakapan hidup

Secara umum kecakapan hidup untuk anak mencakup kecakapan personal, sosial, akademik, dan vokasional. Pembimbing harus dapat mengembangkan kecakapan personal dengan baik sesuai perkembangan anak. Kegiatan bermain, belajar, berketerampilan disajikan dalam bentuk yang menyenangkan akan membantu perkembangan anak dengan baik.

\section{Fungsi seni di sekolah}

Menurut Herawati (1999: 14) Fungsi pembelajaran seni ada enam yaitu: (1) sebagai media ekspresi, (2) sebagai media komunikasi, (3) sebagai media bermain, (4) sebagai media pengembangan bakat seni, (5) sebagai media kemampuan berpikir, (6) fungsi seni sebagai media untuk memperoleh pengalaman estetik. 


\section{METODE PENELITIAN}

Peneliti untuk mendapatkan pemahaman yang mendalam tentang pelaksanaan pembelajaran seni lukis anak di Sanggar Pratista Yogyakarta Pendekatan yang digunakan adalah pendekatan kualitatif. Relevansi pemilihan pendekatan ini adalah bahwa penelitian kualitatif pada prinsipnya adalah mengamati perilaku orang dalam lingkungan kehidupannya, berinteraksi dengan mereka, dan berusaha memahami aktivitas mereka dengan dunia sekitarnya.

Tempat penelitian adalah Sanggar Pratista Kotabaru Yogyakarta yang telah melaksanakan pembelajaran seni rupa anak yang berpengalaman panjang. Alasan memilih subjek penelitian ini, pertama sanggar tersebut merupakan sanggar seni rupa anak yang terkemuka dan berprestasi. Kedua, sanggar tersebut telah melaksanakan pembelajaran yang meyakinkan dan dipercaya masyarakat

Subjek penelitian ini adalah pembimbing dan anak usia dini yang mengikuti pembelajaran seni lukis anak sebagai informan. Sedangkan pengelola, guru pembimbing sebagai informan kunci. Alasan memilih subyek tersebut adalah 1). Semua anak mendapat pelajaran seni lukis anak 2). Pembimbing yang mengajar seni lukis anak memiliki latar belakang pendidikan bukan seni rupa tetapi memiliki pengalaman cukup lama. Penentuan informan berdasarkan snowball sampling melalui wawancara dengan pengelola atau pihak manajemen. 3. Kelas yang dipilih kelas anak usia dini. 4. Anak didik yang dipilih sebagai informan berdasarkan purposive sampling Pemilihan informan tersebut berdasarkan jenis kelamin kelompok berprestasi, kelompok cukup berprestasi

Dalam penelitian ini menggunakan teknik pengumpulan data observasi, wawancara, dan dokumentasi. Ketiga teknik pengumpulan data tersebut digunakan secara bertahap dan terintegrasi.

Teknik analisis data menggunakan pendekatan deskriptif dengan dua cara. Pertama analisis data dilakukan selama proses pengumpulan data. Kedua analisis data dilakukan setelah semua data yang diperlukan terkumpul. Langkah analisis data dalam penelitian ini meliputi: Tahap pertama setelah data terkumpul melalui observasi, wawancara, dan dukumentasi dilanjutkan reduksi data Reduksi data adalah sebagai proses pemilihan, pemusatan perhatian pada penyederhanaan data, pengabstrakan, dan transformasi data kasar yang muncul dari catatan-catatan tertulis di lapangan. Setiap kegiatan reduksi data pada tiap kegiatan pengumpulan data dilanjutnya menentukan kesimpulan. Tahap kedua penyajian data sebagai suatu kumpulan informasi tersusun yang memberikan kemungkinan adanya penarikan kesimpulan dan pengambilan tindakan. Penyajian data dapat berbentuk deskripsi kata-kata. Tahap ketiga adalah menarik kesimpulan dan verifikasi hasil penelitian ini.

\section{HASIL PENELITIAN DAN PEMBAHASAN}

\section{Tujuan Melukis di Sanggar Pratista}

Tujuan yang dikembangkan Sanggar Pratista adalah mendidik anak melalui seni lukis yaitu menjadikan anak pintar, kreatif, dan berbudi pekerti baik. Tujuan tersebut sekaligus sebagai visi dan misi sanggar.Untuk mewujudkan itu metode yang digunakan dengan contoh dan keteladanan. Sanggar tidak membolehkan melukis dengan tema perang atau kekerasan karena tema tersebut akan membentuk jiwa anak menjadi keras, brutal, dan sulit diatur. Untuk membangun percaya diri anak diterapkan metode membuat sket lukisan dengan spidol permanen warna hitam dengan sekali gores tidak boleh diulang-ulang. Cara ini dilakukan untuk melatih keberanian, spotanitas, dan percaya diri yang tinggi.Untuk mewujudkan tujuan itu, kegiatan melukis dilakukan pendekatan individual yang membuat suasana iklim sosioemosional anak dan pembimbing sangat dekat dan bersahabat sehingga proses pembelajaran dapat berjalan dengan baik. Selain itu, dinding tempat belajar melukis dipenuhi dengan hiasan lukisan karya anak sehingga berkesan sangat kondusif dapat memotivasi anak untuk belajar dengan baik.

\section{Kurikulum dan Materi Pembelajaran}

Kurikulum adalah seperangkat program yang harus diselesaikan oleh peserta didik untuk memperoleh kompetensi tertentu. Kurikulum Sanggar Pratista dikembangkan dalam bentuk program bimbingan dan pelatihan melukis yang terdiri dari empat jenjang pelatihan melukis. Kurikulum dalam bentuk cetak seperrti buku memang tidak ada, tetapi kurikulum sebagai program yang tertulis pada pikiran masing-masing pembimbing telah menyatu dan menjiwai para pembimbing untuk mengantarkan anak-anak belajar melukis. Secara garis besar program pelatihan melukis anak-anak ada empat jenjang melukis tersebut sebagai berikut:

a. Tingkat Dasar, dengan materi melukis teknik kering meliputi peralatan spidol permanen hitam, crayon, dan bahan kertas gambar. Program tingkat dasar lama pendidikan empat bulan dengan pembimbingan dua kali dalam satu minggu.

b. Tingkat Menengah, dengan materi melukis teknik kering meliputi peralatan spidol permanen hitam, crayon, dan bahan kertas gambar. Program tingkat menengah lama pendidikan empat bulan dengan jam pembimbingan dua kali dalam satu minggu.

c. Tingkat Terampil, dengan materi melukis teknik kering dan teknik basah, dengan peralatan spidol permanen hitam, crayon, dan cat air, serta media lukis kertas. Teknik yang digunakan bervariasi sesuai perkembangan dan kebutuhan siswa. Program tingkat terampil lama pendidikan empat bulan dengan waktu 
belajar seminggu dua kali

d.

Tingkat Mahir, dengan materi melukis teknik kering dan teknik basah, dengan

peralatan spidol permanen hitam, crayon, dan cat air, acrilic, serta media lukis kertas dan kanvas. Teknik yang dikembangkan bervariasi sesuai kebutuhan siswa. Program tingkat mahir lama pendidikan empat bulan dengan waktu belajar seminggu dua kali.

\section{Pelaksanaan Pembelajaran Melukis}

\section{Persiapan}

Persiapan sanggar dalam pelatihan melukis untuk anak usia dini meliput persiapan secara fisik dan mental. Persiapan fisik berupa penyiapan tempat untuk belajar dengan sistem lesehan dengan satu siswa satu meja belajar kecil. Tempat duduk lesehan dengan alas tikar dan disetting menghadap ke utara. Peralatan dan bahan untuk melukis disediakan sendiri oleh perseta pelatihan, kecuali pada awa pendaftaran masuk pertama kali setiap siswa mendapatkan satu set peralatan melukis terdiri satu sepidol permanen, satu crayon merk Dong A, dan satu kertas gambar/buku gambar. Persiapan secara mental setiap anak yang akan belajar melukis ditempatkan pada tempat yang telah disediakan dengan cara duduk sesuai tempat yang dipilih atau disediakan pihak sanggar. Selanjutnya pembimbing menyapa dan menanyakan apa kabar dan menanyakan keinginan akan menggambar apa dan seterusnya sesuai kontek kondisi setiap anak. Secara psikis setiap siswa yang belajar sudah menyiapkan tema lukisan masing-masing, pembimbing tinggal memotivasi bagaimana mengekspresikan idenya.

\section{Strategi Pembelajaran}

Pembelajaran adalah suatu proses dimana perilaku dibentuk, diubah, dan dikendalikan untuk mencapai suatu tujuan tertentu. Pembelajaran melukis pada anak di Sanggar Pratista lebih tepat disebut dengan pelatihan melukis. Hal ini karena banyak aspek keterampilan yang diajarkan kepada anak. Keterampilan tersebut mencakup keterampilan menemukan imajinasi, keterampilan membua sket, keterampilan mewarnai objek, dan keterampilan lain dalam kerangka anak mengekspresikan dirinya melalui bahasa visual. Metode yang diterapkan sesuai wawancara dengan HK (Tgl 23-8-2007) dikatakan anak senang dengan guru dan pekerjaan, anak dikenalkan dengan peralatan melalui bercerita yang menyenangkan sesuai kontek pada saat melukis seperti puasa, lebaran, natal dan sebagainya. Semua pembimbing sanggar setiap kali memulai mengajar melukis dimulai dengan menyapa anak secara individual dengan selamat siang, apa kabar, mau melukis apa? kepada setiap peserta yang akan mulai melukis. Para peserta hadir di kelas melukis tidak bersamaan, siapa yang datang langsung melukis dan siapa yang sudah selesai melukis dapat meninggalkan kelas lebih awal walaupun jam belajarnya masih ada. Model pembelajaran yang dikembangkan dengan pendekatan individual, dengan satu pembimbing memandu antara satu sampai tiga siswa. Dalam pelaksanaan pembelajaran dilakukan secara santai dan bebas saling tegur sapa dan bermain antar peserta kursus. Dalam pelaksanaan pelatihan orang tua pendamping atau pengasuh siswa dibolehkan mendampingi langsung dalam melukis. Bahkan banyak orangtua atau pendamping ikut dalam membimbing dan mengarahkan anaknya dalam melukis. Hal ini dibolehkan oleh pihak sanggar selama tidak mengganggu kenyamanan proses belajar anak. Banyak anak yang sudah mulai percaya diri dalam pembimbingan yang langsung ditangani pembimbing sanggar, sementara orang tua atau pendamping duduk di luar ruangan.

Model pembelajaran yang dikembangkan di Sanggar Pratista adalah menggunakan metode pemberian contoh. Metode ini disampaikan pada anak bukan untuk memberi contoh suatu objek atau gambar untuk ditiru tetapi diberi contoh pola dasar kemudian anak sisuruh melengkapi contoh pola tersebut sesuai idenya.

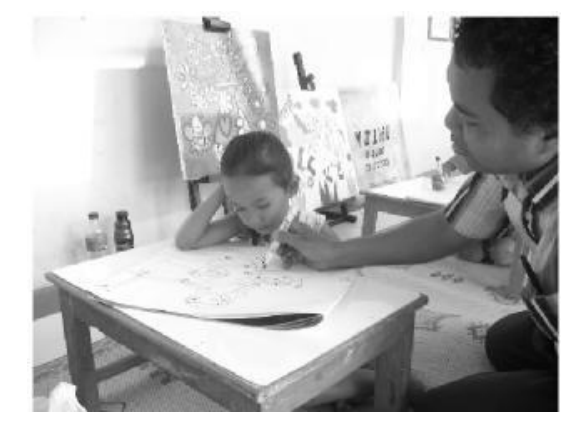

Gambar 1: PE memberi contoh pada Sofa

Seperti yang dilakukan P E dalam memberikan contoh bentuk dengan spidol permanen hitam kepada siswanya bernama Sofa. PE memberikan pola yang tidak lengkap atau garis besar kemudian siswa melanjutkan pola tersebut, sambil memberikan pola pembimbing memotivasi dengan ceritera, pertanyaan, dan bimbingan agar anak percaya diri dapat mengeluarkan idenya. Setiap ada bidang yang masih kosong pembimbing menunjukan bagian tersebut untuk diisi dengan objek sesuai pilihan siswa. Objek tersebut misalnya awan, pohon, orang dan sebagainya. Cara itu dilakukan untuk memberikan motivasi agar anak senang dalam melukis. 


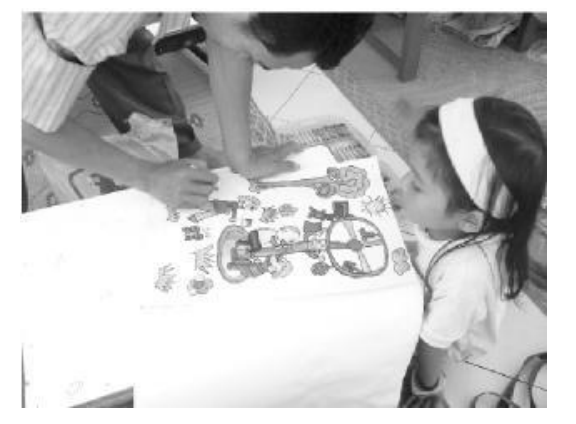

Gambar 2: PY memberikan contoh pola objek pada Diva

PY memberikan contoh pola pada kertas gambar Diva. Semua pembimbing dalam memberikan contoh langsung digoreskan pada kertas gambar siswanya dengan spidol permanen secara spontan, kemudian Diva melanjutkan dan melengkapi pola yang digoreskan pembimbingnya sampai selesai dengan baik. Pemberian contoh pola dikertas gambar anak ini untuk meyakinkan anak untuk bisa melukis dengan baik. Siswa merasa senang diberi contoh, karena dapat memperlancar proses melukis mereka. Diva melukis dengan tema panjat pinang karena sesuai dengan perayaan lomba pada Bulan Agustus bulan peringatan kemerdekaan RI. Anak memiliki ketajaman perasaan mampu merekam kejadian di sekitarnya untuk diangkat sebagai tema lukisan. Kebanyakan anak mengambil tema lukisan sesuai dengan konteks kehidupannya. Diva mampu mengekpresikan ide panjatpinangnya dipandu PY menghasilkan karya yang cukup bagus.

Media yang digunakan anak-anak dalam melukis adalah spidol hitam permanen, crayon, kuas, kertas, dan cat air. Semua media lukis disediakan sendiri oleh peserta. Menggunakan media spidol untuk membuat sket pola gambar bertujuan agar lukisan jelas, spontan, dan tidak diulang-lang atau dihapus. Dengan menggunakan spidol hitam agar anak berani dan percaya diri melakukan sekali gores menjadi bagian dari melukis. Mengapa tidak menggunakan pensil, karena dengan pensil anak akan merasa kurang puas dapat dihapus atau ditumpang, sehingga hasilnya kotor, tebal, dan tidak spontan. Media spidol merupakan media membuat sket atau pola gambar sekali jadi. Cara itu dilakukan untuk membentuk keterampilan mengekspresikan idenya agar anak menjadi percaya diri.

\section{Evaluasi}

Evaluasi yang dikembangkan Sanggar Pratista dengan cara penilaian proses dan penilaian hasil karya. Penilaian ini dilakukan pada akhir paket pembelajaran untuk menentukan kelulusan untuk masuk jenjang berikutnya atau tamat belajar. Penilaian secara formal tidak dilakukan setiap akhir pembelajaran, walaupun di situ terjadi kritik, saran, perbaikan dalam berkarya. Penilaian di sini dimaksudkan untuk memberikan skor setiap kali melukis tidak dilaksanakan oleh pembimbing sanggar. Penilaian dilakukan pada akhir paket pembelajaran dalam bentuk ujian akhir untuk mengisi sertipikat. Penentuan nilai akhir yang dimasukan dalam sertipikat memperhatikan nilai harian dan nilai ujian akhir. Penilaian setiap akhir program dilakukan dengan ujian akhir dengan kriteria penilaian seperti yang dikemukanan P H (wawancara Tgl. 19-9 - 2007) yaitu penilaian proses dengan indikator (1) kelancaran membuat sket, (2) penuangan ide, (3) kesiapan bahan dan alat, (4) pemahaman tema, (5) ketekunan, (6) keseriusan, dan (7) percaya diri.

Penilaian hasil karya dengan kriteria (1) Kesesuaian tema, (2) kreativitas, (3) originalitas, (4) pewarnaan, (5) harmoni keseluruhan. Kedua hasil penilaian ini kemudian digabung menjadi satu menjadi nilai akhir untuk menentukan lulus atau tidak lulus. Walapun penilaian memperhatikan aspek proses dan hasil, penilaian akhir lebih banyak menekankan pada hasil karya yang paling menentukan.

\section{Hasil Karya Siswa Sanggar Pratista}

Berikut hasil karya Leone yang diberi judul "Menari" mereka ingin mengekspresikan ide melalui lukisan tiga lukisan anak menari yang salah satunya adalah pelukisnya sendiri sebagai tokoh sentral dalam lukisan ini. Jika ditanya mana Lione dalam lukisan mereka menunjuk gambar penari yang paling kiri. Lukisan ini dengan latar belakang diberi bentuk awan dan bunga yang diberi contoh oleh pembimbing, kemudian anak meneruskan dan mewarnai sesuai keinginan siswa. Leone mengekspresikan figur penari dengan gaya, warna, dan asesoris yang berbeda, perbedaan inilah yang membuat kesan dinamis dan kreatif dalam lukisan ini

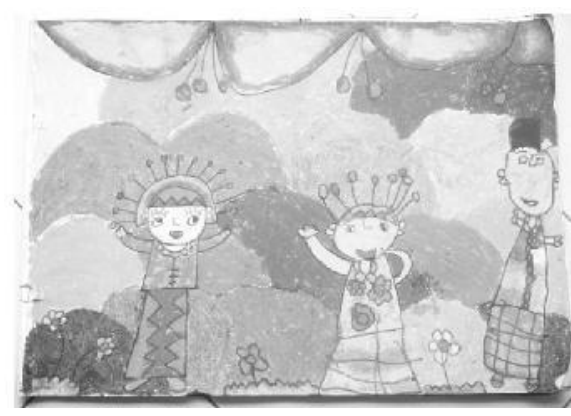

Gambar 3: Judul " menari” karya Lione siswa play group umur 3.6 tahun

Selanjunya lukisan karya Miming siswa TK B dengan judul "Flora dan Fauna",mereka menggambarkan dunia binatang yang unik. Salah satu keunikan lukisan Miming adalah menggambarkan wajah manusia di dalam badan gajah dan jerapah. Hal ini dilakukan karena melihat badan gajah yang lebar dan kosong kalau 
tidak diisi objek akan kelihatan sepi kemudian dilukislah wajah manusia. Wajah manusia yang dilukiskan pada gajah, jerapah, pohon, dan matahari diambarkan senyum ceria sebagai ekspresi pelukisnya gembira dan ceria. Miming dalam melukis sudah dapat memperhitungkan perbandingan bentuk gajah, jerapah, kera, dan kucing. Keberanian ini perlu dipupukkembangkan agar anak lebih beran mengekspresikan dirinya dengan bahasa visual. Penggambaran itu mungkin dapat dimaknai begitu akrab dan sayangnya manusia dengan binatang sehingga dilukiskan menyatu. Keindahan dan keunikan lukisan anak disitulah letaknya, kadang naif, kadang, lucu, juga rasional.

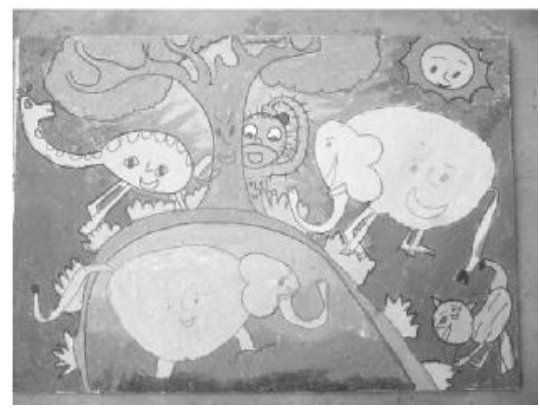

Gambar 4: "Flora Fauna karya Miming

Di Bawah ini lukisan karya "Tea" dengan judul "Takjilan". Tema ini dilukis karena kesan dia menikmati takjilan pada saat bulan puasa sehingga terinspirasi pengalaman takjilan untuk dilukis. Tema ini ditentukan siswa sendiri sesuai kontek pada saat melukis objek itu pada bulan puasa, pembimbing hanya membantu teknis memvisualisasikan pada sebagaian kecil objek. Ketajaman anak mengabadikan peristiwa menarik sesuai kontek dan peristiwa di lingkungannya sangatlah bagus. Hal ini perlu dikembangkan untuk membangun kesadaran anak akan peristiwa dan pengalaman anak terhadap lingkungannya. Anak memiliki kepedulian dengan pengalaman di lingkungannya yang mengesan dapat mengilhami karya lukisnya. Secara visual "Tea" mengekspresikan empat figur anak semua berbeda baik bentuk, gerak, warna walaupun menggambar peristiwa yang sama. Anak kreatif biasanya kurang menyukai pengulangan bentuk yang sama. Kesan stereotipe pada lukisan ini tidak nampak.

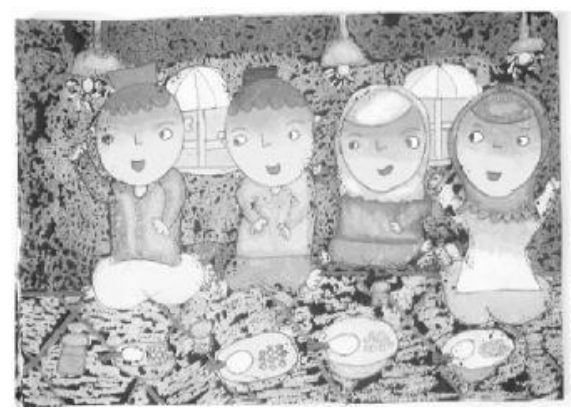

Gambar 5: Judul "Takjilan” Karya Tea

\section{SIMPULAN}

Tujuan pembelajaran seni lukis anak di Sanggar Prastista Yogyakarta adalah untuk membentuk anak menjadi pintar, kreatif, dan berbudi pekerti baik. Untuk mencapai tujuan tersebut sanggar menggunakan strategi pembelajaran melukis dengan pendekatan individual dengan memberikan contoh dan keteladanan dari pembimbing sanggar. Tema melukis tidak boleh menggambarkan peperangan atau kekerasan karena akan membentuk pikiran atau pribadi anak yang keras dan nakal. Melalui melukis membentuk anak yang kreatif terampil, bertanggung jawab, dan percaya diri. Tema lukisan ditentukan anak sendiri sesuai dengan pengalaman dan idenya.

Pembelajaran seni lukis anak yang dikembangkan di sanggar Pratista menggunakan tema sesuai pilihan anak sendiri. Hal ini dilakukan agar anak menjadi senang dan dapat mengembangkan kreasi anak sendiri sesuai idenya. Anak juga melukiskan tema lingkungan sesuai dengan daya tangkap anak terhadap lingkungan mereka tinggal.

Strategi pembelajaran seni lukis anak di Sanggar Pratista menggunakan model pembelajaran individual dengan metode pemberian contoh. Pemberian contoh bukan untuk ditiru melainkan contoh sket pola dasar yang harus diteruskan dan dilengkapi oleh anak menjadi sebuah objek yang lengkap dan indah. Fungsi metode pemberian contoh pada dasarnya adalah untuk memotivasi anak agar dapat mengekspresikan imajinasinya dengan lancar. Pemberian contoh cukup efektif untuk memotivasi anak belajar keterampilan berekspresi, keterampilan penggunaan warna, dan keterampilan menemukan bentuk baru.

Media pembelajaran melukis menggunakan spidol hitam, crayon, dan cat air. Media melukis tersebut digunakan secara bersamaan saling mengisi (mixed media)

Penilaian pembelajaran seni lukis anak di Sanggar Pratista menggunakan penilaian pada akhir paket program untuk mengisi sertipikat tanda tamat belajar. Pada kegiatan melukis harian pembimbing sanggar memberi kritik dan saran 
untuk membangun dan memperbaiki karya anak. Penilaian akhir karya lukis menggunakan kriteria proses dengan indikator (1) kelancaran membuat sket, (2) penuangan ide, (3) kesiapan bahan dan alat, (4) pemahaman tema, (5) ketekunan, (6) keseriusan, dan (7) percaya diri. Penilaian hasil karya dengan kriteria (1) Kesesuaian tema, (2) kreativitas, (3) originalitas, (4) pewarnaan, (5) harmoni keseluruhan. Kedua hasil penilaian ini kemudian digabung menjadi satu nilai akhir untuk menentukan kelulusan.

Hasil karya seni lukis anak Sanggar Pratista baik, indah, dan dinamis dengan penggunaan goresan dan warna tebal dan kuat. Penggambaran objek utama dibuat dinamis bervariatif sehingga nampak indah dan unik. Pembuatan latar belakang bervariasi dan masih nampak ada kesan stereotipe. Penggunaan warna warna kuat dengan efek pastel kombinasi dengan cat air memberikan kesan yang lebih bagus dan mantap. Karya anak menggambarkan dunia anak dengan tema pilihannya sendiri sesuai pengalaman dalam kehidupannya. Jika anak melukiskan kehidupan anak salah satu tokoh sentral dalam tema lukisan adalah pelukisnya sendiri.

\section{DAFTAR PUSTAKA}

Hamalik Umar. 1994.Pengembangan Kurikulum dan Pembelajaran. Bandung: Trigenda Karya.

Herawati Ida Siti, Idris.1999. Pendidikan seni rupa, Depdiknas: Dikti

Kemis, S. \& Mc Taggart, R. (1998) The Action Research Planner. $3^{\text {rd }}$ ed. Victoria: Deakin University.

Mattil Edward.1971.Meaning In Craft. New Jersey:Prentice Hall.

The Liang Gie. 1996. Filsafat seni sebuah pengantar. Yogyakarta: PUBIB

Tilaar HAR.1999.Pendidikan,Kebudayaan, Dan Masyarakat Madani Indonesia. Bandung: Remaja Rosda Karya.

Usman Moh. Uzer. 1999. Menjadi Guru Profesional. Bandung. 